\title{
What makes us optimistic?: Psychosocial factors as predictors of dispositional optimism in young people
}

\section{¿Qué nos hace optimistas?: Factores psicosociales predictores al optimismo disposicional en jóvenes}

\author{
Constanza Londoño Pérez \\ Marcela Velasco Salamanca \\ Ivonne Alejo Castañeda \\ Paula Botero Soto \\ Ivonne Joliet Vanegas \\ Universidad Católica de Colombia, Colombia \\ Rec (25 de Enero de 2013) Acept (20 de Marzo de 2014)
}

\begin{abstract}
The present study descriptive - correlational pretended to describe the relationship between dispositional optimism, psychosocial factors such as coping, spirituality and stressful life events in parents or family caregivers and teachers and sociodemographic factors such as age, education level, family composition, gender and socioeconomic status. The sample was formed by 319 high school students (male and female), between 12 and 18 years old; 138 parents and 19 teachers. It was used the Cuestionario de Optimismo Disposicional (Londoño et al., 2013); the Coping Style Inventory (Archila \&Londoño, 2004), Stressful Life Events Scale (WHO); the Index of Spirituality and Wellness (Daaleman \& Frey, 2004). The comparative and associative multivariate analysis showed that mixed coping in young people (social support, fantasy and self-blame) in addition to mixed coping in parents (problem solving and social support) predicted dispositional optimism in young people.

Keywords: optimism, coping, young people.
\end{abstract}

\section{Resumen}

El presente estudio descriptivo correlacional pretende describir la relación entre optimismo disposicional y factores psicosociales como afrontamiento, espiritualidad, acontecimientos vitales estresantes y optimismo disposicional en padres o familiares acudientes y maestros; y con factores sociodemográficos (edad, nivel educativo, conformación familiar, género y estrato). La muestra fue de 319 jóvenes, entre 12 y 18 años de ambos géneros, 138 padres y 19 maestros. Se usaron el Cuestionario de Optimismo Disposicional (Londoño et al., 2013), el Inventario de Estilos de Afrontamiento (Archila \& Londoño, 2004), la Escala de Eventos Vitales Estresantes de la OMS, el Índice de Espiritualidad y Bienestar (Daaleman \& Frey, 2004). Los análisis multivariantes comparativos y de asociación evidenciaron que el afrontamiento mixto en jóvenes (búsqueda de soporte social, fantasía y auto culpa), sumado al afrontamiento mixto en los padres (solución de problemas y búsqueda de soporte social), predecían el optimismo disposicional en los jóvenes.

Palabras clave: optimismo, afrontamiento y jóvenes. 


\section{Introduction}

The optimism has been defined as the person tendency to be motivated by beliefs about the desired results are easily achievable. These statements have a positive effect in psychological and physical health (Brannon \& Feist, 2001; Gómez \& Londoño, 2013; Londoño; 2009). Optimism includes a positive vision about what people have and help the individual satisfaction in terms of reaching the goals in a short future with some program effort, if they have not been reached yet (Marrero \& Caballeira, 2010). Optimism has a meaningful impact on perceived quality of life in ill people and help to recover from illness events (Morales et al., 2011; Ridder, Schreurs \& Bensing, 2004; Scheier \& Carver, 1985; 2014), because optimism enhances the individual capacity to copy with general tension (Fournier, Ridder \& Besing, 2002; Gordon, Feldman, Crase \& Schoen, 2002; Kennedy \& Hughes, 2004; Ortiz, Ramos \& Vera, 2003; Perera \& Mcllven, 2014; Scheier \& Carver, 2014).

Therefore, optimism is a psychological resource to enable individual coping the adverse situations (Remor, Amorós \& Carboles, 2006). For some authors, optimism is a learned dimension of the personality, as a result of the interaction between inheritance - environment; other authors affirm optimism is a part of the genetic base of the personality, expressed as a dispositional feature in the middle of external situations and the individual interpretation of them (Kim \& Seidlitz, 2002; Seligman, 2005). This dilemma justifies the studies to recognize if the optimism is part of an inherited structural base of the personality or a cognitive and behavioral style learned through the interaction of several psychosocial factors, as the social interaction.

Otherwise, there is a negative extremity called pessimism in opposition to the optimistic view (Salas, 2008; Seligman, 2005). The pessimistic style implies the vision of external, nonpermanent and situational causes to explain the negative events; also, a vision of internal, permanent and generalized causes to different areas of the individuals life (Remor et al., 2006).

Instead, dispositional optimism has generalized expectancies about success that lead the person action to get great results, even the person shows willing to persist in the adverse situation. The positive effects of the dispositional optimism in health are considered in the self - regulation theory, in terms of the individual with positive expectancies about the future have more probability to make an effort to reach their goals (Ridder et al., 2004 cited by Vera-Villarroel, Córdova-Rubio \& Celis-Atenas, 2009).
The positive effect of the dispositional optimism in health has been widely studied (Ridder et al., 2004) and it has showed the beneficial impact in the physical wellbeing and good health, as well as the effective recovery and adaption to illness in chronic patients (Chico, 2002). In general, it is well known that if people hold favorable expectancies about their situation and increase their efforts to obtain great results (Martínez-Correa, Reyes del Paso, García-León \& González-Jareño, 2006; Remor, et al., 2006), they certainly gain the best health outcomes.

The optimistic person is realistic in the situations and uses his potential to solve the problem in an effective way. This has been confirmed through the Parkinson, cardiometabolic risk, arterial pressure, general physical functioning, disease progression (Gison, Dall'armi, Donati, Rizza\& Guiaquinto, 2014; Oreskovic \& Goodman, 2013; Senkus, Cardoso \& Pagani, 2014). The people using optimism as a coping resource with positive attitude to stressful circumstances can have better levels of life. In this sense, Kennedy and Hughes (2004), Covey and Davis (2004) and Black and Reynolds (2011) found that cognitive functioning in terms of positive and optimistic style prevents depression and anxiety, improves the physical and emotional functioning, generates better adapting processes and tends to perceive problems as preventable, adopting healthier styles of life.

Optimism comes up when the individual needs to response to difficult situation with potential damage or stressful events (Britton, Sliter \& Jex, 2012; Solis \& Vidal, 2006; Taylor, 2007). There are some universal situations related to stress reactions in most of the people; life events viewed by people as stressful in terms of the interpretation of the events as higher than the response capacity to coping them. Depending on the age of the individual, the events have the power of affect the psychological wellbeing and can have dysfunctional effects in emotional, behavioral and cognitive levels.

According to the optimistic curve along life, the parents as adults tend to be more optimistic than younger people, in terms of behaviors or actions to get positive results they are waiting for. However, young people try to make actions to relieve discomfort; usually they deny discomfort, take emotional distance of the situation and avoid it in cognitive and behavioral ways (Lench \& Ditto, 2008). On the other hand and regarding gender and sociodemographic aspects, there are not differences in terms of optimism, except people with more economic resources tend to be more pessimistic about the future (Fischer \& Chalmers, 2008; Londoño, 2009).

Stressful events are coping in different ways for people and Lazarus and Folkman (1986) proposed coping styles 
or ways of answer to internal or external demands; these demands are view as excessive or challenging the personal resources (Brannon \& Feist, 2001; Taylor \& Stanton, 2007). Coping process starts with individual assessment of an event as stressful, with unpleasant and intense emotions. Coping answers begin in an emotional context and often the first task in coping is related to regulate negative emotions that can block instrumental actions of coping (Folkman \& Moskowitz, 2004; Jaser et al., 2007; Patzelt \& Shepherd, 2011).

In general, there are two general styles or coping types, one of them is positive and oriented to solve the problem; the individual leads efforts to carry out a plan designed to resolve the stressful situation. The other one is negative or focused on avoiding the stressful event, minimizing the unpleasant emotion. Problem - focused coping implies a view centered in the real change of the situation; the negative coping is oriented to change the emotion (Gordon et al., 2002); in some cases the problem is left behind or the solution is delayed temporary while the impact of event is happening, in other cases, it is done in a stable way.

However, there is no maladaptive coping style universally (Compas, Connor-Smith, Saltzman, Thomsen \& Wadsworth, 2001), because a problem - focused coping can be useless in a permanent event with no possibility of control and it is better for the individual relieve the emotion to improve the quality of life and manage the initial emotional response. Some researchers have identified individual and stable differences in coping, improving the ability to deal with stressful events and leading to feel less discomfort and better health outcomes.

These differences are due to the cognitive, behavioral and emotional responses to the situations and no related to variables such as age (Castro, 2002). What makes the variation in the response to stress is related to personal competences, social support and context (Glozah \& Pevalin, 2014; Sandín, 2002). Nevertheless, some authors have noticed the tendency to avoiding coping in teenagers that is exacerbated at the beginning of the youth and it is becoming stable in the adulthood, depending on the behavioral options offered by models and context. In the specific case of adults, the coping style is stable but it is not invariable, because it is not a fixed element of personality, it is a process more than a trait and the change is define by the learning capacities of the individual more than age, gender or economic condition.

Coping is also mediated by a group of positive beliefs used to process the information in a way in which the adversity is viewed as unstable, solvable and manageable, in this scenario it is more probable the adjustment to the situation. On the other hand, attributions related touncontrollability and stability of the illness has been associated to avoiding coping (Taylor \& Stanton, 2007).

Nonetheless, some psychological resources as spirituality seem to maximize the capacity to coping negative events and the optimistic assessment that everything is going to be alright. Spirituality is related to essence, individuality and the feeling of being itself as a person. This construct has been considered as hard to measure because the difficulties in delimitation due to the confusion between spirituality and religiosity. It is clear that spirituality is focused on beliefs and perceptions about the goodness (Weaver \& Flannelly, 2004), kindness and transcendence expressed in the spiritual meaning, the daily spiritual experiences and the purpose of life. The religiosity is regarding faith, religious beliefs and practice, aspects that converge and overlap each other in practice transcendental and religious daily life (Sooet et al., 2009). Faith gives the suffering person a sense and meaning of the hard situations such as diseases and adversity, giving a control feeling; spirituality has been linked to bigger adjustment and effective coping in chronic diseases, as cancer (Shinall, Ehrenfeld \& Guillamondegui, 2014) and AIDS (Lyon et al., 2011; Cho \& Park, 2013).

Specifically, religious beliefs and practices, beliefs in goodness and kindness (Kazemi, 2010), the self - reported spirituality (Lucchetti, Lucchetti \& Koenig, 2011) and influenced on end-of-life decision making (Webb \& Stouffer, 2014) all of them has been associated to the positive response to treatments to improve mental health, decrease drugs abuse (Ragsdale, Hegner, Mueller \& Davies, 2014), health behavior change (Fried et al., 2012) and increase quality of life (Hasanovic \& Pajevic, 2012; Moreira-Almeida \& Koening, 2006; Robinson, Cranford, Webb \& Brower, 2007).

In some cases, higher spirituality has been linked to tendency to have less healthier behaviors (Boswell, Kahana \& Dilworth-Anderson, 2006; Lillis, Gifford, Humphreys \& Moos, 2008; McCullough \& Laurenceau, 2005) because the person thinks is protected; this idea is related to the optimistic belief no realistic, in which a bias of external control is waiting for protection of God despite of the risky behaviors to health. The relationship between optimism and spirituality has not been studied enough.

In opposition, it has been found that people coping with spiritual strategies seem to have advantages in comparison to people who do not use them. Litwinczuk and Groh (2008) found that people more spiritual achieved easily: a) evoke emotions and feelings of comfort, b) perceive more stronghold, empowerment and control, c) diminish the emotional charge caused by the disease, d) feel they receive social support, e) feel spiritual support through the close relation perceived 
with goodness, f) give sense to the disease and accept it, g) perceive help in the process of maintain health, h) relieve fear and uncertainty related to death, i) self - acceptance and j) reduce self - blame. These authors also affirmed that increasing spiritual activity is linked to diminishing of stress and disappearing unpleasant feelings.

Therefore, to study coping and spirituality as personal conditions related to optimistic beliefs about beneficial events can provide more information to understand the source of optimistic trend. In addition, understanding the effect of some factors linked to the appearance and maintain of cognitive and behavioral styles centered in dispositional optimism is important if the goal is approach health problems, from intervention perspective or prevention view. Hence, the aim of the present study was to determine if there is any relation between sociodemographic aspects (age, education level, family composition, gender and socioeconomic status) and psychosocial factors (coping, spirituality, stressful life events and dispositional optimism) in parents, teachers and young people between 12 and 18 years old.

\section{Method}

The present descriptive correlational study looked for assessing the predictive association between sociodemographic variables such as age, gender, education level and socioeconomic status and psychosocial factors as coping styles, spirituality, stressful life events, family composition, and dispositional optimism in parents, teachers and young people.

\section{Participants}

The sample was stratified by levels of intact groups; it was composed by 319 male and female teenagers between 12 and 18 years old, with a median of 14.8 years. They were students at three schools: one of them was mixed gender, the other one was a female school and the other one was a male school. It was possible to get contact with 138 parents or family caregivers and the sample also included 19 teachers qualified by the teenagers as a meaningful model. Parents or family caregivers were in average 41.59 years old with a standard deviation of 7.95 and a rank from 18 to 66 years old.

\section{Instruments}

Dispositional Optimism Questionnaire (Cuestionario de OptimismoDisposicional in original language): it is a test designed by Londoño, Hernández, Alejo\&Pulido (2013) Colombian people. It assesses people's trend to interpret in a positive or negative way the situations, to wait for good results and to provide personal resources in pro of getting the solutions to daily events. The questionnaire has 20 items with three answer options: one of them is pessimistic (centered in the permanent expectancy that something wrong is going to happen), the other one is an optimistic bias no realistic (focused on waiting for something really good to happen no matters the person' action) and the last one is dispositional optimism (permanent expectancy that something good will happen with actions to facilitate it). To classify the profile, the same options are used and they are the factors measured through the items. The profile is obtained reviewing answer trends and the factor average of them. The level of reliability of the test is high with alpha of .85 .

Questionnaire of coping forms (Cuestionario de formas de afrontamiento in Spanish): This questionnaire was developed by Folkman and Lazarus and adapted to Spanish population by Vitaliano, Russo, Carr, Maiuro and Becker (1985). The adaptation to Colombia was made by Londoño and Archila (2004) and revalidated by Rueda and VélezBotero (2010), with 46 items clustered in seven subscales or factors, measuring responses of people in daily stressful situations. Coping styles measured by this test are: problem - focused coping, self - blame, naive or illusory thinking, social support search, minimizing the threat and mixed style, with Likert scale 5 options from "always" to "never". Cronbach Alpha reached to Colombian population was .85.

Index of Spirituality and Wellness: Daaleman and Frey (2004) developed this instrument to test spirituality and wellbeing of people, with 12 items divided in two domains, six of them regarding self-efficacy and the other six related to vital scheme, independent one group from the other. The scale has a good reliability level of .97 . The instrument includes statements related to 2 dimensions mentioned above and people have to respond in Likert scale with 5 options from completely disagree to completely agree. The higher scores indicate low feeling of inability, high sense of vulnerability and lack of sense of life.

Stressful Life Events Scale (Escala de Acontecimientos Vitales Estresantes): It was designed by Oliva, Jiménez, Parra and Sánchez-Queijá (2008), based on 23 events previously classified for World Health Organization as potentially stressful for most of young people. These events can be 
academic, familiar, peers and personal aspects. Cronbach alpha is.72. The classification is obtained by adding the number of stressful events experienced for people; the scores are higher if the events have happened in the last year.

Sociodemographic data form: With this instrument was collected information about date of birth (to calculate the age at the moment of the study), education level (primary school, high school, technical studies, university and postgraduate degree), gender (male or female) and socioeconomic status (based on public services bill from the place the people live).

\section{Procedure}

Stage 1: Selecting the sample. It was made after the authorization to collect the information was obtained.

Stage 2: Data Collecting. The instruments were applied in a group format with practitioners in psychology, after the participants signed the informant consent (for young people the format were signed for parents or family caregivers). The application to parents or family caregivers was made by the same trained team in a parent school meeting scheduled by the schools. The application to teachers was done under similar control conditions as well as with young people and parents - family caregivers in a meeting scheduled by the directors.

Stage 3: Creation of data bases and analysis of results. The data bases were in SPSS format, compatible with AMOS applicative to carry on purifications of models and finally, to determine the final predictive model.

\section{Results}

First of all, descriptive analysis about participants and measured variables were made. In a second place, an ANOVA was carried on, to determine if there were significant differences between psychosocial variables in those people scoring high in dispositional optimism factor in comparison to people scored high in pessimism factor. Before the predictive model, correlative analyses were done using statistics depending of the sort of variables measured (Pearson, Spearman and Kendal) and a model was identified using regression. At the end, a structural equation analysis was made to identify the final explicative model.

The sample was balanced in terms of gender; most of the teenagers said they have socioeconomic status of 2 or 3 ; in a higher proportion they were the oldest son, then it was the youngest member of the family and after that in a lower proportion there were the middle siblings; most of the $60 \%$ of the teenagers lived with nuclear families (father, mother and sons) in average they were 5 people living in the same house (Table 1)

Table 1.

Sociodemographic and family caractheristics of teenagers.

\begin{tabular}{|c|c|c|c|c|c|c|}
\hline Variable & $\mathrm{f}$ & $\%$ & \multirow{2}{*}{\multicolumn{2}{|c|}{$\begin{array}{l}\text { Variable } \\
\text { S o c i o e c on } . \\
\text { Status }\end{array}$}} & $\mathrm{f}$ & $\%$ \\
\hline Gender & & & & & & \\
\hline Male & 165 & 51.7 & \multicolumn{2}{|l|}{1} & 43 & 13.5 \\
\hline Femaler & 154 & 48.3 & \multicolumn{2}{|l|}{2} & 98 & 30.7 \\
\hline & & & \multicolumn{2}{|l|}{3} & 159 & 49.8 \\
\hline $\begin{array}{l}\text { Place in the } \\
\text { family }\end{array}$ & & & \multicolumn{2}{|l|}{4} & 7 & 2.2 \\
\hline Only child & 61 & 19.1 & & & & \\
\hline Younger son & 72 & 22.6 & \multicolumn{2}{|c|}{ Type of family } & & \\
\hline Middle son & 61 & 19.1 & \multicolumn{2}{|l|}{ Nuclear } & 204 & 63.9 \\
\hline Oldest son & 109 & 34.2 & \multicolumn{2}{|l|}{ Extensive } & 108 & 33.9 \\
\hline Twin & 1 & 0.3 & \multicolumn{2}{|l|}{ Other } & 7 & 2.2 \\
\hline & $\mathrm{X}$ & sd & Min & Max & & \\
\hline \multicolumn{7}{|l|}{$\begin{array}{l}\text { Family } \\
\text { Composition }\end{array}$} \\
\hline $\begin{array}{l}\text { People } \\
\text { who live with }\end{array}$ & 4.74 & 1.85 & 2 & 15 & & \\
\hline Place at home & 2.90 & 1.36 & 1 & 7 & & \\
\hline
\end{tabular}

sd: standar desviation, f: frecuency.

Young people showed high scores in optimism (22.6), low pessimism (2.17), an average of 4.58 stressful life events, medium scores in spirituality (18.15), with avoiding coping (2.70) and self-blame (2.85). Regarding gender and coping styles with ANOVA, there were no significant differences. 
Table 2.

Descriptive statistics of optimism, coping and spirituality in young people.

\begin{tabular}{lrrrrrrrr}
\hline Variable & \multicolumn{2}{c}{ Male } & \multicolumn{2}{c}{ Female } & Min & Max & X & sd \\
\hline & \multicolumn{1}{c}{ X } & sd & X & sd & & & & \\
Optimism & 50.30 & 10.11 & 44.79 & 13.93 & 14 & 29 & 22.60 & 4.05 \\
Pessimism & 2.01 & 1.74 & 1.98 & 1.82 & 0 & 8 & 2.17 & 2.02 \\
Stress ful Life Events & 2.88 & 2.40 & 5.24 & 2.86 & 0 & 10 & 4.58 & 2.98 \\
Spirituality & 17.49 & 5.74 & 17.97 & 3.48 & 0 & 30 & 18.15 & 5.05 \\
Coping Styles & & & & & & & & \\
Problem solving & 2.56 & 0.39 & 2.64 & 0.32 & 1.33 & 3.47 & 2.59 & 0.40 \\
Social support search & 2.45 & 0.57 & 2.46 & 0.50 & 1.33 & 3.83 & 2.44 & 0.55 \\
Avoiding style & 2.64 & 0.30 & 2.79 & 0.28 & 1.90 & 3.60 & 2.70 & 0.35 \\
Fantasy & 2.35 & 0.64 & 2.45 & 0.63 & 1.00 & 3.43 & 2.39 & 0.67 \\
Self - blame & 2.67 & 0.47 & 2.83 & 0.45 & 1.00 & 4.00 & 2.85 & 0.59 \\
\hline
\end{tabular}

sd: standar desviation.

In the group of parents or family caregivers, they were highly optimistic (23.67) with coping centered in avoiding (2.64) and self - blame (2.56). They reported 3.17 stressful life events and a high level of spirituality (20.13).

Table 3.

Descriptive statistics of optimism, coping and spirituality in parents or family caregivers.

\begin{tabular}{lllll}
\hline Variable & Min & Max & X & sd \\
\hline Optimism & 14 & 29 & 23.67 & 3.78 \\
Pessimism & 0 & 9 & 1.75 & 1.89 \\
Coping Styles & & & & \\
Problem solving & 0.60 & 3.13 & 2.22 & 0.48 \\
Social support search & 0.67 & 3.83 & 2.51 & 0.68 \\
Avoiding style & 0.00 & 3.60 & 2.64 & 0.60 \\
Fantasy & 0.43 & 4.00 & 2.38 & 0.68 \\
Self - blame & 0.00 & 4.00 & 2.56 & 0.83 \\
Stressful Life Events & 0 & 10 & 3.17 & 2.32 \\
Spirituality & 0 & 28 & 20.13 & 6.24 \\
\hline
\end{tabular}

sd: standar desviation.

In the case of teachers, it was a high level of optimism (23.73), coping focused on avoiding, followed by fantasy trend (2.85) and social support search (2.83).

Comparing teenagers with optimistic bias trend no realistic and teenagers with pessimistic trend regarding the measured variables, it was found that optimistic teenagers had emotion - focused coping, especially with avoiding style $(\mathrm{p}=.00)$, fantasy $(\mathrm{p}=.012)$ and self blame $(\mathrm{p}=.04)$. This comparison was possible because the subgroups were formed with 30 teenagers or more.

Table 4.

Descriptive statistics of optimism, coping and spirituality in teachers.

\begin{tabular}{lrrrc}
\hline Variable & Min & Max & \multicolumn{1}{c}{ X } & \multicolumn{1}{c}{ sd } \\
\hline Optimism & 13 & 28 & 23.73 & 4.01 \\
Pessimism & 0 & 11 & 1.00 & 1.71 \\
Coping Styles & & & & \\
Problem solving & 1.87 & 2.80 & 2.30 & 0.27 \\
Social supportsearch & 1.83 & 3.67 & 2.83 & 0.49 \\
Avoiding style & 2.30 & 3.70 & 3.07 & 0.41 \\
Fantasy & 2.14 & 3.29 & 2.85 & 0.31 \\
Self - blame & 1.25 & 3.25 & 2.82 & 0.35 \\
Stressful Life Events & 1 & 7 & 3.92 & 1.25 \\
Spirituality & 1 & 27 & 12.42 & 4.49 \\
\hline
\end{tabular}

sd: standar desviation.

In the bivariate correlational analysis, all the possible matches were reviewed between the teenagers' variables, between teenagers, parents and teachers variables. Only significant and direct associations between high optimism, avoiding coping and self -blame were found, as well as avoiding style in teenagers and the amount of stressful life events reported by parents. 
Table 5 .

Comparison ANOVA between optimistic and pessimistic teenagers regarding psychosocial variables.

\begin{tabular}{lcc}
\hline Variable & $\mathrm{F}$ & $\mathrm{p}$. \\
\hline Avoiding & 5.255 & .00 \\
Fantasy & 2.828 & .01 \\
Self - Blame & 3.379 & .04 \\
\hline
\end{tabular}

p: significance level.

In addition, significant indirect associations were found between the amount of stressful life events reported by teenagers and avoiding style, between social support searching styles in teenagers and avoiding

style in parents, between problem - focused coping in teenagers and self - blame style in parents (Table 6). All the variables with the highest correlation were included, because in exploratory studies is necessary to recognize as many intervening factors as possible in a phenomenon.

The multivariant analysis with the outcome variable (dispositional optimism) generated a model with $34 \%$ of variance explained, including teenagers variables as social support searching style and fantasy, parents or family caregivers' variables as problem - focused coping and support search style (Table 7).

Table 6.

Correlations between teenagers and parents scores in the measured variables.

\begin{tabular}{|c|c|c|c|c|c|c|}
\hline & \multicolumn{3}{|c|}{ Teenagers } & \multicolumn{3}{|c|}{ Parents } \\
\hline Teenagers & Pessimism & Avoiding & $\begin{array}{l}\text { Self - } \\
\text { Blame }\end{array}$ & Avoiding & $\begin{array}{c}\text { Self } \\
- \text { Blame }\end{array}$ & SLE \\
\hline $\begin{array}{l}\text { Optimism } \\
\text { Pessimism }\end{array}$ & $-.627^{*}$ & $\begin{array}{l}.369^{* *} \\
-.379^{* *}\end{array}$ & $.296^{*}$ & & & \\
\hline $\begin{array}{l}\text { Problemsolving } \\
\text { Social support }\end{array}$ & & & & $\begin{array}{l}-.400^{* *} \\
-.272^{*}\end{array}$ & $-.336^{*}$ & \\
\hline Avoiding & & & & & & $.266 *$ \\
\hline
\end{tabular}

SLE: Stressful Life Events, ${ }^{*} p=.05 ; * * p=.01$

Table 7.

Predictive model of optimism in teenagers.

\begin{tabular}{|c|c|c|c|c|c|c|c|c|}
\hline & & $\begin{array}{r}\text { Unstand } \\
\text { Coeffi }\end{array}$ & $\begin{array}{l}\text { dized } \\
\text { nts }\end{array}$ & $\begin{array}{l}\text { Standardized } \\
\text { Coefficients }\end{array}$ & & & Confid & eInterval \\
\hline & & & & & & & Lower & HigherLimit \\
\hline & & $\mathrm{B}$ & sd & Beta & $\mathrm{t}$ & $\mathrm{p}$ & Limit & \\
\hline 1 & $\begin{array}{l}\text { (Constant) } \\
\text { TeenagerCoping Style }\end{array}$ & -6.12 & 6.86 & & -0.89 & 0.37 & -19.94 & 7.69 \\
\hline & ProblemSolving & 3.75 & 1.43 & 0.37 & 2.62 & 0.01 & 0.87 & 6.63 \\
\hline & Social Support & -3.26 & 1.02 & -0.44 & -3.17 & 0.00 & -5.33 & -1.19 \\
\hline & Fantasy & -4.60 & 1.74 & -0.68 & -2.64 & 0.01 & -8.10 & -1.09 \\
\hline & Parents & & & & & & & \\
\hline & Problem - FocusedCoping & 5.22 & 1.74 & 0.74 & 2.98 & 0.00 & 1.69 & 8.74 \\
\hline & Social Support Search Coping Style & -3.86 & 1.46 & -0.65 & -2.64 & 0.01 & -6.80 & -0.92 \\
\hline
\end{tabular}

The structural equation model explained $41 \%$ of the variance and the predicting factors of dispositional optimisms in teenagers were: problem solving coping in parents, fantasy style in teenagers, with a negative relationship with social support searching style in parents and self - blame in teenagers. 


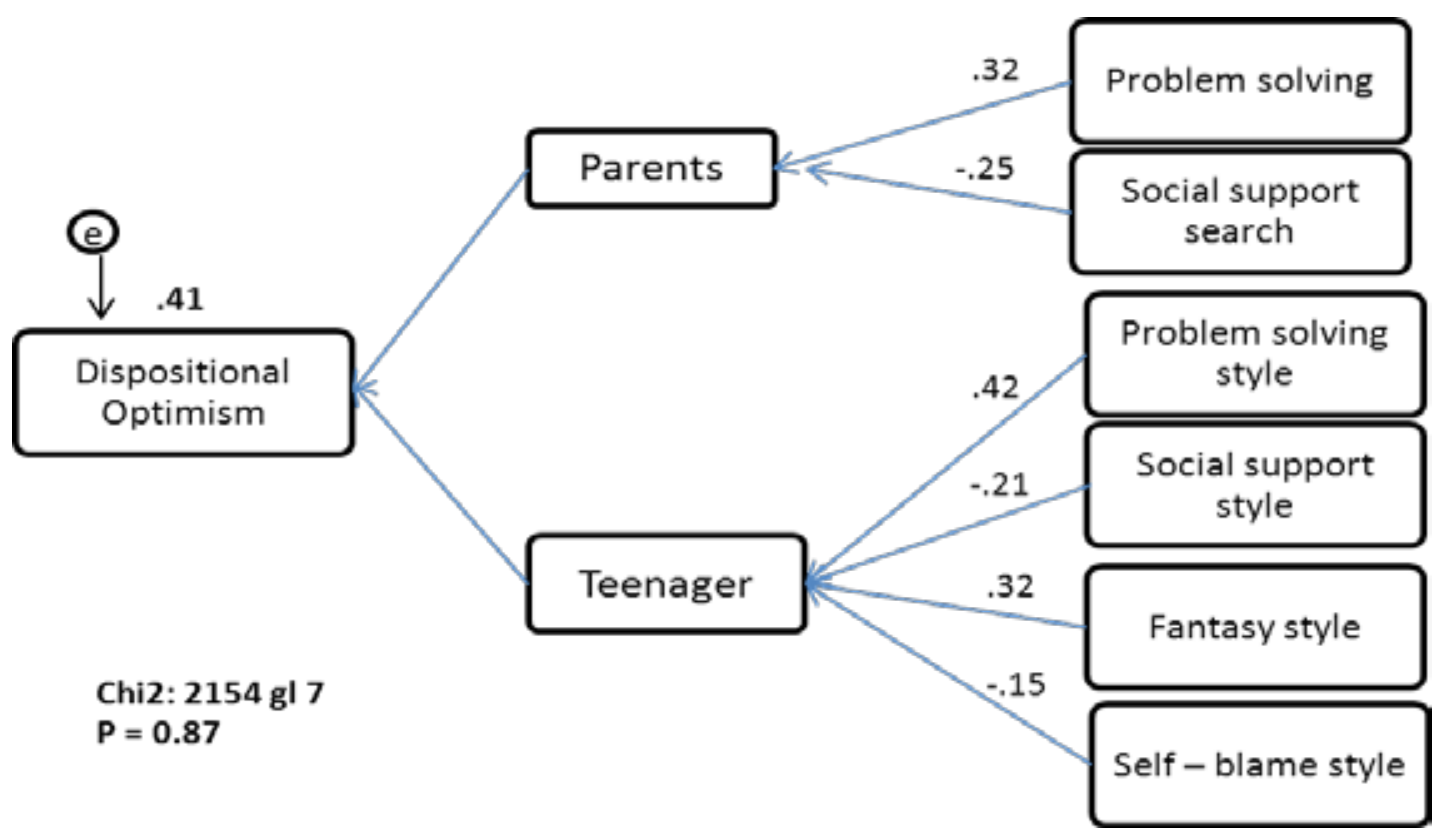

Figure 1. Predictive model of dispositional optimism.

\section{Discussion}

In summary, the predictive model of dispositional optimism explained $43 \%$ of variance and included teenagers' variables as social support search style, fantasy and self blame, parents and family caregivers' variables as problem solving coping and social support searching style and none of the teachers variables were taken into the model. Thereby, null hypothesis is accepted, because it looks like there is no relationship between socioeconomic level, family composition, gender and spirituality with dispositional optimism in the group of teenagers.

Regarding spirituality, that previously had been associated to better answers in stressful situations (Johnson, Sheets, \&Kristeller, 2008; Kaskutas, Turk, Bond \& Weisner, 2008; Pardini et al., 2000), it is recommended to make further investigations, using instruments more elaborated than the interview used in the present study and even reconfirm the present results about spirituality, in terms of the moderate level found in teenagers versus high level of spirituality in parents.

On one hand, the results indicate optimism is a learnt dimension of the personality, its appearance is mediated for individual variables such as personal tendency to look for social support and fantasy as a way to imagine the possible solutions of the difficult situation (Seligman, 2005), as well as parents variables such as the tendency to solve problems and looking for social support. Searching social support was identified by Taylor \& Stanton (2007) as a strategy that is not negative or maladaptive, people can look for help in other people, enhancing real and perceived social support, with the feeling they are important to others. However, searching social support is beneficial in the solution of situations when the individual keep the responsibility on the situation and does not charge the other people with it.

Carver and Connor-Smith (2010) propose that if the coping strategy is focused only on relieving emotions, coping can be considered inappropriate, because the individual does not look for a real solution but he is trying to feel discomfort.

Then, the person who looks for social support to unburden or resolve the situation is more consistent with dispositional optimistic style and the social group is considered as an important resource in the solution of stressful events (Birditt \& Antonucci, 2008; Moser, 2009; Sohl \& Moyer, 2009). The individual assumes responsibility by making behaviors and actions oriented to solve the problem under an optimistic sight of the possibility of reach the desired results (Augusto Landa, Aguilar-Luzón \& Salguero Duarte, 2008; Cabarcas $\&$ Londoño, 2014). This trend to look for social support, from a positive perspective has been reviewed for some authors as a way to optimize resources in the pretention to get a solution (Gison et al., 2014; Oreskovic \& Goodman, 2013; Senkus et al., 2014).

On the other hand, the beneficial optimism in teenagers is also associated to coping focused on fantasy, in which person leads the effort in imagination of ideal situations where the solution is achievable and accessible. There was 
said before that optimistic people have some imaginative capacity (Seligman, 2005), so the hope is about the good results will happen and they are visualized (Samper, Mestre, Tur \& Cortés, 2008). This strategy helps the individual to release tension and thinking clearer about the solutions and options, but this style is not beneficial without problem solving style, in which the individual is responsible of the situation. Nonetheless, the findings are not completely conclusive and it is necessary to carry on more studies to identify two types of coping person with the tendency to look for social support.

Furthermore, the coping styles like social support searching and fantasy are combined with self-blame, in which the individual thinks problems are associated to personal behavior. In this sense, Martínez-Correa et al. (2006) and Marrero and Caballeira (2010) studies showed optimistic people use self - criticism to determine the level of personal responsibility in the situation and to regulate their own behavior. Still, it has to be done more research to see if coping oriented to self-blame includes some characteristics of self - criticism and in this way, promote positive results and great adjustment in the stressful situation.

Dispositional optimism of teenagers was associated to the existence of mixed coping style in parents, in which social support searching and problem solving styles are combined. It is possible that parents have been models of mixed styles, influencing the optimistic point of view of teenagers, but it was not associated to father's optimism. Some authors like Ortíz et al. (2003) and Vera-Villaroel and Guerrero (2003) had noticed in their studies the relationship between parent's typical coping style and teenagers 'coping styles; also, they found a close relation between teenager optimism and positive skills in solving social problems (Hernández \& Londoño, 2013). In the same direction, Solís and Vidal (2006) have proposed a link between family models of coping and coping showed by teenagers.

Most of the teenagers who participated in the study were low and middle class in the socioeconomic level (status 2 and 3), living with a nuclear family, in average with 5 members inside the family and 15 people at the same place. However, none of these variables were significantly related to high scores of optimism. They showed high scores of optimism and there were no significant differences in media scores between teenagers, parents and meaning teachers. Taylor and Staton (2007) identified a moderate optimistic trend with better capacity to deal with stressful events, the person waits for positive results as well as a feeling to be able to execute more control on the situation. Nonetheless, the tendency to emotion - focused coping can mark the difference and it makes the level of adjustment is not optimal, because the incontrollable and permanent event of stress has been associated with poor adjustment to diseases (Gison et al., 2014; Oreskovic \& Goodman, 2013; Senkus et al., 2014) and other stressful situations. Thus, the action would be oriented to change the emotion and no the situation as it is expected (Gordon et al., 2002; Velasco, Botero \& Londoño, 2011). Emotion - focused coping has been found frequently in young people no matters gender, as it was found in this and others studies (Hampel \& Petermann, 2006), these strategies are centered in control of the moment and release the tension more than the option of visualize requirements in long term. Other investigations have found gender differences (Babakhani, 2011; Becker \& Curry, 2006; Klimstra et al., 2009; Mpofu \& Thomas, 2006; Renk \& Creasey, 2003) but in populations of different cultures and that could be the reason of the difference with the present study.

In this sense, a lot of studies have been found that exaggerated optimism make people to ignore the real limitations, because they think that independently the conditions and their behaviors, the outcomes always will be good (Ridder et al., 2004; Larsman, Eklof \&Torner, 2012; Seligman, 2005; Covey \& Davies, 2004; El-Anzi, 2005), but with significant differences between those with an optimistic bias no realistic and the pessimistic people: extreme optimistic tended to have more styles focused on avoiding, fantasy and self-blame than pessimistic people.

Previous studies like Folkman and Moskowitz (2004) and Sandín (2002) have been shown that in general, no matters the predominant style, there is a tendency to regulate negative emotions as first reactions in coping, interfering with actions and effective solutions of the problems. This regulation can be through avoiding, fantasy or self - blame as in the case of teenagers, or can be through social support searching and avoiding as in the case of parents.

Pessimism was related to less fantasy, avoiding and self-blame, in opposition to previous researches showing a marked tendency in pessimistic people to self - blame in the situations, considering as internal and stables the causes of them, associated with personal characteristics and low capacity of modification (Remor et al., 2006). Likewise, teenagers reported more stressful life events in less time, in comparison with parents and teachers, but due to the unequal sizes in the groups, these comparisons have to be taken carefully.

Regarding coping styles in teenagers and their association with parents coping styles, it was found as in other studies (Solís \& Vidal, 2006) that problem solving style in teenagers was negative associated to avoiding and self - blame 
style in parents. At the same time, social support style in teenagers was negative related to avoiding style in parents. These results mean that if parents were less avoiding and focused on self - blame, the teenagers would show more strategies centered in problem solving and social support.

There are some limitations to be present related to the results. One of them is the difficulty in the parents' interview that leaded to lost 100 teenagers data. Other limitation is the interview used to measure spirituality because there is no validate instrument to Colombian population. The other limitation is the type of transversal study, because the results and the model have been confirmed in future studies.

\section{References}

Archila, D., \& Londoño, C. (2004).Afrontamiento y consumo de cigarrillo en universitarios. Experiencias Investigativas. Universidad Santo Tomás.

Augusto Landa, J., Aguilar-Luzón, M., \& Salguero de Ugarte, M. (2008). El papel de la IEP y del optimismo/pesimismo disposicional en la resolución de problemas sociales: un estudio con alumnos de trabajo social. Revista Electrónica de Investigación Psicoeducativa, 6, 363-382. Recuperado de: http://www.investigacion-psicopedagogica.org/revista/ new/ContadorArticulo.php?242

Babakhani, N. (2011). The effects of social skills training on self- esteem and aggression male adolescents.Procedia -Social and Behavioral Sciences, 30, 1565-1570. doi: 10.1016/j.sbspro.2011.10.304

Becker, S., \& Curry, J. (2006). Interactive Effect of Substance Abuse and Depression on Adolescent Social Competence. Journal of Clinical Child and Adolescent Psychology, 36, 469-475. doi: 10.1037/a0025754.

Birditt, K., \& Antonucci, T. C. (2008). Life sustaining irritations? Relationship quality and mortality in the context of chronic illness. Social Science \& Medicine, 67, 1291-1299. doi: 10.1016/j. socscimed.2008.06.029

Black, J. \& Reynolds, W. (2013). Examining the relationship of perfectionism, depression, and optimism: Testing for mediation and moderation. Personality and Individual Differences, 54 (3), 426-431. doi: 10.1016/j. paid.2012.10.012

Boswell, G. H., Kahana, E., \& Dilworth-Anderson, P. A. (2006). Spirituality and Healthy lifestyle behaviors: Stress Counter-balancing effects on the well-being of older adults. Journal of Religion and Health, 45. doi:10.3390/rel2010029

Brannon, L. \& Feist, J. (2001). Psicología de la Salud. Madrid: Paraninfo Thomson Learning.

Britton, A., Sliter, M., \& Jex, S. (2012). Is the glass really half-full? The reverse-buffering effect of optimism on undermining behavior.Personality and Individual Differences, 52 (6), 712-717. doi: 10.1016/j. paid.2011.12.038

Cabarcas, K. y Londoño, C. (2014). Trastornos de la conducta alimentaria, imagen corporal, afrontamiento y optimismo como predictores de aceptación de cirugías plásticas cosméticas. Psicología y Salud, 24 (2), 199-219.

Carver, C. \& Connor-Smith, J. (2010). Personality and Coping. Annual Review of Psychology, 61, 679-704. doi: 10.1146/annurev. psych.093008.100352

Carver, S., Scheier, M., \& Segerstrom, S. (2010). Optimism. Clinical Psychology Review, 30, 879-889. doi:10.1016/j.cpr.2010.01.006

Castro, M. J. (2002). Anorexia Nerviosa. Guías Clínicas, 2, 1-4.

Chico, E. (2002). Optimismo disposicional como predictor de estrategias de afrontamiento. Psicothema, 14, 544-550.
Cho, D. \& Park, C. (2013). Crecimiento tras el trauma: Revisión general y estado actual. Terapia Psicológica, 31 (1), 69-79. doi: http://teps.cl/ files/2013/02/8908-6-CHO-y-PARK-ok.pdf

Compas, B. E., Connor-Smith, J. K., Salzman, H., Harding, B., Thomsen, A., \& Wadsworth, M. E. (2001). Coping with stress during childhood and adolescence: Problems, progress, and potential in theory and research.Psychological Bulletin 127, 87-127. doi: 10.1037/00332909.127.1.87

Covey, A., \& Davies, D. M. (2004). Are people little realistic optimist? She depends how you ask to him? British Journal of Health Psychology, 1, 11-39. doi: 10.1348/135910704322778713

Daaleman, T. P., \& Frey, B. (2004). The Spirituality Index of Well-Being: A New Instrument for Health-Related Quality-of-Life Research. Annals of Family Medicine, 2, 406 - 411. doi: 10.1348/135910709X479799

El-Anzi, F. O. (2005). Academic achievement and its relationship with anxiety, self-esteem, optimism, and pessimism in Kuwaiti students. Social Behavior and Personality: An international journal, 33, 95-104. doi:http://dx.doi.org/10.2224/sbp.2005.33.1.95

Fischer, R. \& Chalmers, A. (2008). Is optimism universal? A meta-analytical investigation of optimism levels across 22 nations. Personality and Individual Differences, 45, 378-382.

Folkman, S. \& Moskowitz, J. T. (2004). Coping: pitfalls and promise. Annual Review. Psychology, 55, 745-774. doi: 10.1037/00219010.91.5.1037

Fried, T. Redding, C., Robbins, M., Paiva, A., O’Leary, J., \& Iannon, L. (2012). Promoting advance care planning as health behavior change: Development of scales to assess decisional balance, medical and religious beliefs, and processes of change. Patient Education and Counseling, 86 (1), 25-32. doi: 10.1016/j.pec.2011.04.035

Garnefski, N., \& Kraaij, V. (2002). Relationships between cognitive emotion regulation strategies and depressive symptoms: A comparative study of five specific samples. Journal of Adolescent Health, 30, 326-335.

Gison, A., Dall'armi, V., Donati, V., Rizza, F., \& Giaquinto, S. (2014). Dispositional optimism and Parkinson's disease. Annals of Physical and Rehabilitation Medicine, 57 (1), e364. doi: 10.11138/ FNeur/2014.29.1.005

Glozah, F. \& Pevalin, D. (2014). Social support, stress, health, and academic success in Ghanaian adolescents: A path analysis. Journal of Adolescence, 37 (4), 451-460. doi: 10.1016/j.adolescence.2014.03.010

Gómez, C. \& Londoño, C. (2013). Modelo predictor del consumo responsable de alcohol y el comportamiento típicamente no violento en adolescentes. Salud y Drogas, 13 (1), 23-33. Recuperado de: www. redalyc.org/pdf/839/83928046003.pdf

Hampel, P., \& Petermann, F. (2006). Perceived stress, coping, and adjustment in adolescents. Journal of Adolescent Health, 38, 409-415. doi:10.1016/j.jadohealth.2005.02.014

Hasanović, M. \& Pajević, I. (2012). Religious moral believes and quality of life amongst war veterans in Bosnia and Herzegovina negatively associated with severity of trauma experiences and anxiety. European Psychiatry, 27 (1), 1. Recuperado de: http://www.sciencedirect.com/ science/article/pii/S0924933812742979

Hernández, L., \& Londoño, C. (2013). Imagen corporal, IMC, afrontamiento, depresión y riesgo de TCA en jóvenes universitarios. Anales de Psicología, 29 (3), 748-761.

Jaser, S., Champion, J., Reeslund, K., Keller, G., Merchant, MJ., Benson, M., \& Compas, B. (2007). Cross-situational coping with peer and family stressors in adolescent offspring of depressed parents. Science Direct. Journal of Adolescence, 30, 917-932.

Johnson, T. J., Sheets, V. L., \& Kristeller, J. L. (2008). Identifying mediators of the relationship between religiousness/spirituality and alcohol use. Journal of Studies on Alcohol and Drugs, 69 (1), 160-170.

Kaskutas, L., Turk, N., Bond, J., \& Weisner, C. (2008).Spirituality evidence based medicine, and alcoholics anonymous, American Journal Psychiatry, 165, 1514-1517. doi: 10.1176/appi.ajp.2008.08050678

Kazemi, M. S. (2012). The relationship between religious coping strategies and mental health in MS patient. Procedia - Social and Behavioral Sciences, 5,1387-1389. doi: http://dx.doi.org/10.1080/09638280802532779 
Kennedy, D. K. \& Hughes, B. M. (2004). The optimism-neuroticism question: an evaluation based on cardiovascular reactivity in female college students. The Psychological Record, 54, 373.

Kim, Y., \& Seidlitz, L. (2002). Spirituality moderates the effect of stress on emotional and physical adjustment. Personality and Individual Differences, 32, 1377-1390. doi: http://dx.doi.org/10.1016/S01918869(01)00128-3

Klimstra, T., Hale, W., Raaijmakers, Q., Branje, S., \& Meeus, W. (2009). Maturation of Personality in Adolescence. Journal of Personality and Social Psychology, 96, 898-912. doi: 10.1037/a0014746

Lazarus, R., \& Folkman, S. (1986). Estrés y Procesos Cognitivos. Madrid, España: Martínez Roca.

Lench, H. C., \& Ditto, P. H. (2008). Automatic optimism: Biased use of base rate information for positive and negative events. Journal of Experimental Social Psychology, 44, 631-639.

Lillis, J., Gifford, E., Humphreys, K., \& Moss, R. (2008). Assessing spirituality/religiosity in treatment environment: the treatment spirituality/religiosity scale. Journal Substance Abuse Treat, 35, 427-433.

Litwinczuk, K. M., \& Groh, C. J. (2008). The Relationship Between Spirituality, Purpose in Life, and Well-Being in HIV-Positive Persons. Journal of the Association of Nurses in AIDS care, 18, 13-22. doi: 10.1016/j.jana.2007.03.004.

Londoño, C., Hernández, L., Alejo, I., \& Pulido, D. (2013). Diseño y validación del cuestionario de optimismo disposicional/pesimismo EOP. Universitas Psychologyca, 12 (1), 139-155.

Londoño, C. (2009). Optimismo \& salud positiva como predictores de la adaptación a la vida universitaria. Acta Colombiana de Psicología, $12,95-107$.

Lucchetti, G., Lucchetti, A., \& Koenig, H. (2011). Impact of spirituality/ religiosity on mortality: comparison with other health interventions. The Journal of Science and Healing, 7 (4), 234-238. doi: 10.1016/j. explore.2011.04.005

Lyon, M., Garvie, P., Kao, E., Briggs, L., He, J., Malow, R., D’Angelo, 1., \& McCarte, R. (2011). Spirituality in HIV-infected Adolescents and Their Families: family centered (face) advance care planning and medication adherence. Journal of Adolescent Health, 48 (6), 633-636. doi: http://dx.doi.org/10.1016/j.jadohealth.2010.09.006

Marrero, R., \& Caballeira, M. (2010). El papel del optimismo y del apoyo social en el bienestar subjetivo. Salud Mental, 3, 39-46.

Martínez-Correa, A., Reyes del Paso, G., García-León, A., \& GonzálezJareño, M. (2006). Optimismo pesimismo disposicional y estrategias de afrontamiento del estrés. Psicothema, 18, 66-77.

McCullough, M. E. \& Laurenceau, J. P. (2005). Gender and the natural history of self-rated health: Findings from a 59-year longitudinal study. Health Psychology, 23, 651-655.

Morales, A., Arenas, M.D., Reig-Ferrer, A., Álvarez-Ude, F., Malek, T., Gil, E., y Cotilla, E.M. (2011). Optimismo disposicional en pacientes en hemodiálisis y su influencia en el curso de la enfermedad. Revista Nefrología, 31, 199-205.

Moreira-Almeida, A., \& Koenig, H. G. (2006). A cross-cultural study of spirituality, religion, and personal, beliefs as components of quality of life. Social Science \& Medicine, 62, 1486-1497.

Moser, G. (2009). Quality of life and sustainability: Toward person-environment congruity. Journal of Environmental Psychology, 1, 351-357.

Mpofu, E. \& Thomas, K. (2006). Classroom Racial Proportion: Influence on Self-Concept and Social Competence in Zimbabwean Adolescents. The Journal of Genetic Psychology, 167, 93-111.

Oliva, A., Jiménez, J., Parra, Á., y Sánchez- Queija, I. (2008). Acontecimientos vitales estresantes, resiliencia y ajuste adolescente. Revista de Psicopatología y Psicología Clínica, 13, 53-62.

Oreskovic, N. \& Goodman, E. (2013). Association of optimism with cardiometabolic risk in adolescents. Journal of Adolescent Health, 52 (4), 407-412. doi: 10.1016/j.jadohealth.2012.09.011

Ortiz, J., Ramos, N., \& Vera-Villarroel, P. E. (2003). Optimismo y Salud: estado actual e implicaciones para la Psicología Clínica y de la Salud. Suma Psicológica, 10, 119-134.
Pardini, D., Plante, T. G., Sherman, A., \& Stump, J. E. (2000). Religious faith and spirituality in substance abuse recovery: Determining the mental health benefits. Journal of Substance Abuse Treatment, 19, 347-354.

Patzelt, H. \& Shepherd, D. (2011). Negative emotions of an entrepreneurial career: Self-employment and regulatory coping behaviors. Journal of Business Venturing, 26 (2), 226-238. doi: 10.1016/j.jbusvent.2009.08.002

Perera, H. \& McIlveen, P. (2014). The role of optimism and engagement coping in college adaptation: A career construction model. Journal of Vocational Behavior, 84 (3), 395-404. doi: http://dx.doi.org/10.1016/j. jvb.2014.03.002

Ragsdale, J., Hegner, M., \& Davies, S. (2014). Identifying religious and/or spiritual perspectives of adolescents and young adults receiving blood and marrow transplants: a prospective qualitative study. Biology of Blood and Marrow Transplantation, 20 (8), 1242-1247. doi: 10.1016/j. bbmt.2014.04.013

Remor, R., Amorós, M., \& Carboles, J. (2006). El optimismo y la experiencia de ira en relación con el Malestar físico. Anales de Psicología, $22,37-44$.

Renk, K., \& Creasey, G. (2003).The relationship of gender, gender identity, and coping strategies in late adolescents. Journal of Adolescence, 26, 159-168. doi: 10.1016/S0140-1971(02)00135-5

Ridder, D., Schreurs, K., \& Bensing, J. (2004). The relative benefits of being optimistic: Optimism as a coping resource in multiple sclerosis and Parkinson' disease. British Journal of Health Psychology, 5, 141.

Robinson, E. A., Cranford, J. A., Webb, J. R., \& Brower, K. J. (2007). Six-month changes in spirituality, religiousness, and heavy drinking in a treatment-seeking sample. Journal Studies Alcohol Drugs, 68, 282-290.

Rueda, C. \& Vélez-Botero, H. (2010). Características psicométricas de un cuestionario de estilo de afrontamiento. Típica Boletín Electrónico de Salud Escolar, 6 (2), art. 5. Recuperado de: http://www.tipica.org/ index.php?option $=$ com_content $\&$ view $=$ article $\& i d=143 \&$ Itemid $=11$

Salas, J. (2008). Control, health and welfare.Suma Psicológica, 15, 15-42

Samper, P., Mestre, A., Tur M., \& Cortés, M. (2008). Agresividad y afrontamiento en la adolescencia. Una perspectiva intercultural. International Journal of Psychology and Psychological Therapy. 8, 431-440.

Sandín, B. (2002). El estrés: Un análisis basado en el papel de los factores sociales. Revista Internacional de Psicología Clínica y de la Salud, 3 , 141-157.

Scheier, M. F. \& Carver, C. S. (1985). Optimism, coping and health: Assessment and implications of generalized outcome expectancies. Health Psychology, 4, 219-247.

Scheier, M.F. \& Carver, C.S. (2014). Dispositional optimism. Trends in Cognitive Sciences, 18 (6), 293-299. doi: 10.1371/journal.pone.0097752

Searward, G., \& Kemp, S. (2000). Optimism bias and student debt. New Zealand Journal of Psychology, 29, 17-25.

Seligman, M. (2005). La auténtica felicidad. Barcelona, España: Ediciones B.

Senkus, E., Cardoso, F., \& Pagan, O. (2014). Time for more optimism in metastatic breast cancer? Cancer Treatment Reviews, 40 (2), 220-228. doi: 10.1016/j.ctrv.2013.09.015

Shinall, M., Ehrenfeld, J., \& Guillamondegui, O. (2014). Religiously affiliated intensive care unit patients receive more aggressive end-of-life care. Journal of Surgical Research, 190 (2), 623-627. doi: 10.1016/j. jss.2014.05.074

Siegel, K., \& Schrimshaw, E.W. (2002). The perceived benefits of religious and spiritual coping among older adults living with HIV/AIDS.Journal of the Scientific Study of Religion. 41, 91-102. doi: 10.1111/14685906.00103

Sohl, S. J., \& Moyer, A. (2009).Refining the conceptualization of a futureoriented self-regulatory behavior: Proactive coping.Personality and Individual Differences. 47, $139-144$.

Solís, C., \& Vidal, A. (2006). Estilos y estrategias de afrontamiento en adolescentes. Revista de Psiquiatría y Salud Mental Hermilio Valdizan, 6, 33-39.

Soo, Y., Lee, H. O., Fitzpatrick, J. J., Kim, S., Marui, E., Lee, J. S., \& Cook, P. (2009). Spirituality, Depression, Living Alone, and Perceived Health Among Korean Older Adults in the Community. Archives of Psychiatric Nursing, 23 (4), 309-322. 
Taylor, S.E. (2007). Psicología de la Salud. México: Mc Graw Hill.

Taylor, S. E. \& Stanton, A.L. (2007). Coping resources, coping processes, and mental health. Annual Review of Clinical Psychology 3, 377-401. doi: 10.1146/annurev.clinpsy.3.022806.091520

Tonigan, J. S., Miller, W. R., \& Schermer, C. (2002). Atheists, agnostics and Alcoholics Anonymous. Journal of studies on alcohol, 63,534-41.

Tuck, I., Alleyne, R., \& Thinganjana, W. (2006). Spirituality and Stress Management in Healthy Adults.Journal Holistic Nursing, 24, 245-253. doi: 10.1177/0898010106289842

Velasco, M., Botero, P., \& Londoño, C. (2011). Calidad de vida y potencial humano. En: C. Londoño. Eds. Avances y Perspectivas en Psicología de la Salud. (pp. 91-125). Bogotá: División de Psicología de la Salud-Colpsic. Vera-Villarroel, P., \& Guerrero, A. (2003). Diferencias en habilidades de resolución de problemas sociales en sujetos optimistas y pesimistas. Universitas Psychologica, 2, 21-26.
Vera-Villarroel, P., Córdova-Rubio, N., \& Celis-Atenas, K. (2009). Evaluación del optimismo: un análisis preliminar del Life Orientation Test versión revisada (LOT-R), en población chilena. Universitas Psychologica, 8, 61-67.

Vitaliano, P. P., Russo, J., Carr, J. E., Maiuro, R. D., \& Becker, J. (1985). The ways of coping checklist: Revision and psychometric properties. Multivariate Behavioural Research, 20, 3-26.

Zlatev, M., Pahl, S., \& White, M. (2010). Perceived risk and benefit for self and others as predictors of smokers' attitudes towards smoking restrictions. Psychology \& Health, 25, 167-182. doi: $10.1080 / 08870440802372449$

Weaver, A. J., \& Flannelly, K. (2004). The role of religion/spirituality for cancer patients and their caregivers. Southern Medical Journal, 97, 1210-1214. 